\title{
Lessons on the Right to Health Litigation and MDGS for Implementing Health Related SDGS in South Africa
}

\author{
Ademola Oluborode Jegede \\ Department of Public and International Law, University of Venda, South Africa \\ ademola.jegede@univen.ac.za.
}

Annette Lansink

University of Venda, South Africa

and

Cornelius CA Hagenmeier

University of Venda, South Africa

DOI//http://dx.doi.org/10.4314/gjds.v15i1.1

\begin{abstract}
In 2015, the Sustainable Development Goals (SDGs) replaced the Millennium Development Goals (MDGs), but due to its newness at the global stage, how the implementation of the former can be shaped by courts remains unclear. The authors conducted an extensive and systematic review of existing literature on MDGs, SDGs and health litigation cases decided by the Constitutional Court in South Africa. The rationale for this approach is to examine whether the SDGs connect with the right to health and how the court can shape the policy environment for the implementation of SDGs. It was found that the SDGs connect with the right to health and that the Constitutional Court has influenced the MDGs policy environment, hence, can contribute to the implementation of health related SDGs in South Africa. It is concluded that Courts' role as a platform of accountability, a catalyst of change in the policy environment and agent of social mobilization are important lessons for implementing health related SDGs in South Africa. It is recommended that government and indeed other stakeholders should take into consideration the role of court as they pursue the implementation of health related SDGs in South Africa.
\end{abstract}

Keywords: Health related SDGs, Litigation, Right to Health, Social Mobilisation 


\section{Introduction}

In 2015, following the activities of the Open Working Group on Sustainable Development Goals (SDGs) which was established under the United Nations General Assembly (UNGA), the SDGs, a set of 17 goals and 169 targets were adopted via Resolution 70/1 of the UNGA, otherwise referred to as the 2030 Agenda for Sustainable Development (UNDP, 2016; UNGA, 2015). In several aspects, the SDGs replaced the Millennium Development Goals (MDGs) as the framework for international action in the field of development until 2030 (UNDP, 2016; UNGA, 2015). According to the work of Fehlinga et al. (2013), health is prominent in the MDGs framework in that three goals namely, the reduction of child mortality rates, improvement of maternal health and combating HIV/AIDS, malaria and other diseases are directly health-related. Other MDGs indirectly connected to health are the tackling of poverty, universal primary education, gender equality and empowerment of women, environmental sustainability and development partnership.

Alston (2005), in a ground-breaking essay demonstrates that human rights can be used in assessing the implementation of MDGs. The SDGs aim at building on the experiences of the MDGs, for instance, the preamble of the SDGs announces that it seeks to 'build on the Millennium Development Goals' and succeed where MDGs have failed. This signifies that the acceptability or otherwise of the link of MDGs to human rights may shape the approach of government and other stakeholders in the implementation of SDGs. However, due to the newness of the SDGs on the global stage, it is not yet properly developed how accountability through human rights, in particular the litigation of the right to health, can shape policy towards the implementation of the SGDs in South Africa. Yet, unless there is connection of MDGs to the right to health, it will be difficult to sustain an argument that accountability through the litigation on the right to health can shape the environment for policy and mobilization campaigns for the implementation of health related SDGs in South Africa. In particular, the health related goals in the SDGs, according to the analysis of the Office of the High Commissioner for Human Rights (OHCHR, 2010), are Goal 3 which expressly deals with ensuring healthy lives and promotion of well-being for all at all ages, and other goals such as Goal 6 on availability and sustainable management of water and sanitation, Goal 12 on sustainable consumption and production patterns, Goal 13 dealing with climate change and its impacts, Goal 14 which focuses on conservation and sustainable use 
of the oceans, seas and marine resources for sustainable development, and Goal 15 dealing with degradation and biodiversity loss. ${ }^{1}$

\section{Method of Data Collection}

To determine how the courts can help shape policy towards the implementation of the SGDs in South Africa, the study assessed and reflected on existing literature and case law dealing with the right to health. To discuss all literature in relation to the subject and cases before all the courts in South Africa is impossible. Hence, the website of the Southern African Legal Information Institute (SAFLII) which publishes legal information, was consulted to elicit literature and the cases discussed in this article. In relation, the Constitutional Court was purposively selected for its status as the final authority on all constitutional rights in South Africa (Roux, 2016). Using the search term, namely, 'MDG', 'SDG', 'access to health services', 'healthy well-being', and 'state and private actors', no retrieved case was found that discusses MDG and SDG in relation to right to health in South Africa. However, four cases met the remaining criteria to be selected for discussion. Against that background, the study demonstrates the implication of litigation before courts as a platform of accountability, a catalyst of change in the policy environment and agent of mobilization for campaigns on health related SDGs in South Africa.

\section{Connecting International Standard on the Right to Health to MDGS AND SDGS}

At the United Nations level, as Ruger (2013) correctly observes, the right to health stems primarily, but not exclusively, from Article 12 of the International Covenant on Economic, Social and Cultural Rights (ICESCR) which recognizes 'the right of everyone to the highest attainable standard of physical and mental health.' Other instruments with provisions on the right to health at that level are Universal Declaration of Human Rights (UDHR, Article 25), the Convention on the Rights of the Child (CRC, Article 24), Convention on the Elimination of Discrimination against Women (CEDAW, Article 12), and the Convention on the Rights of Persons with Disabilities (CRPD, Article 25). The normative standards of the right to health is set out by the Committee on Economic, Social and Cultural Rights (CESCR) in UN General Comment No 14 (2000) which clarified the nature of the right to health and how it can be achieved in a given State. Some salient notions from UN

1 OHCHR 'Sustainable Development Goals and related human rights'. Available at: http://www.ohchr. org/Documents/Issues/MDGs/Post2015/SDG_HR_Table.pdf/.Accessed 27th February, 2017. 
General Comment 14 include the requirement that health facilities and services be available, accessible, culturally acceptable, and of appropriate scientific and medical quality. In addition, the general comment demands that the right to health entail not only that key minimum standards of care be met or exceeded, but that basic preconditions such as food, housing and sanitation, adequate supply of safe and potable water, education, and essential drugs as defined under the World Health Organisation are met in realising the right to health (UN General Comment 14, 2000).

Although, it is not a human rights instrument, Forman et al. (2013) submit that international human right to the highest attainable standard of physical and mental health (the right to health) is compatible with the MDGs which expired in 2015 and can guide the formulation of future goals as a replacement. This is not surprising in that even if there is no specific reference to human rights in the MDGs, it is evident in its enabling instrument, that is, the Millennium Declaration and a range of reports on MDGs (OHCHR, 2008; Nelson, 2007; Alston, 2005; FukudaParr, 2003). The Millennium Declaration highlights the collective willingness of states to respect human rights of all humankind without distinction (UNGA, 2000). As Ghai and Cottrell (2011) have written, the Declaration also identifies that the respect for human rights principles such as equality and non-discrimination as essential to the fulfilment of the MDGs. In fact, the necessity of right to health for implementing health-related MDGs was set out by Paul Hunt, the United Nations Special Rapporteur on the right of everyone to the enjoyment of the highest attainable standard of physical and mental health from 2002-2008. In a report highlighting the contribution that the platform of right to health can make to the attainment of health-related MDGs, the Special Rapporteur (UN, 2004: 2) noted that 'at least three of the eight MDGs are directly related to sexual and reproductive health.'

Similarly, the relevance of human rights and arguably the right to health standards to the SDGs is not difficult to imagine. For instance, the 2030 Agenda for Sustainable Development on 25 September 2015 which foregrounded the SDG indicates its strong connection with human rights (UNGA Resolution 70/1, 2015). The new Agenda extensively makes reference to international human rights law instruments including the UN Charter, the Universal Declaration of Human Rights, and the Declaration on the Right to Development (UNGA Resolution 70/1, 2015: para 10). It states that the SDGs aim to 'realize the human rights of all' (UNGA Resolution 70/1, 2015: preamble) and emphasises the obligations of the State 'to respect, protect and promote human rights and fundamental freedoms for all, without distinction of any kind' (UNGA Resolution 70/1, 2015: para 19). It further provides 
that the new Agenda is 'to be implemented in a manner that is consistent with the... obligations of states under international law' (UNGA Resolution 70/1, 2015: para 18). Underlying the important role of accountability in achieving the objective, the Agenda underscores the commitment of governments to 'accountability to citizens' (UNGA Resolution 70/1, 2015: para 47). That there is connection between human rights and SDGs is further reinforced by the Human Development Report (HDR) 2015 which shows that human rights is central to the implementation of SDGs and arguably its components relating to health , namely Goals 6, 12, 13, 14 and 15 as earlier mentioned. However, the challenge to MDGs which is equally of importance to the implementation of SDGs at the domestic level is the issue of accountability. Neither the MDGs nor the SDGs have a binding status on governments committed to their implementation.

In South Africa, the 2015 MDG report suggests the need for the improvement of the protection of human rights and access to justice as a strategic objective (STATSSA, 2015), a development that indicates that human rights, and arguably the right to health will be useful in reporting on and engaging with health related SDGs in South Africa. The report does not, however, specifically mention the role of court or social campaigns. This fact reflects comments of authors such as Persson et al. (2016) and Alston (2005), which underscore the absence of accountability in relation to the implementation of MDGs at the national level. In particular, as Unterhalter (2013) and Hulme (2009) observe, the implementation of MDGs at the national level focused on operational and programmatic goals, rather than building on mechanisms of accountability, internationally recognized human rights standards and principles to which governments are obliged to adhere. Yet, the United Nations Committee for Development Policy (UN CDP, 2015), Lomazzi et al. (2012) and Lomazzi et al. (2014) find that the policy environment of MDGs at the national level can benefit from accountability through human rights actions in courts. While this development offers hope that state officials and policy implementers can be engaged in a manner that ensures human rights, in particular, the right to health, it is not clear what the direction will be as South Africa prepares for the implementation of SDGs.

\section{Role of Courts in the Implementation of Health- Related MDGS and Lessons for SDGS}

Arguably, the courts, in particular the Constitutional Court, has influenced the MDGs policy environment and can contribute to the implementation of health related SDGs in South Africa. This position is based on the premise that the Constitutional Court has served and can still serve as a platform of accountability, 
a catalyst of change in the policy environment, and as a catalyst of social mobilization for the implementation of SDGs.

\section{As a Platform of Accountability}

Generally the role of court as a vehicle of accountability for ineffective service delivery has been a subject of academic attention. According to Gloppen (2008), court room litigation offers the platform of holding leadership accountable to their responsibilities for rights in relation to health care service delivery. Accessing the court has its own challenges, though. For instance, there is socio-legal scholarship suggesting that the 'haves' have an upper hand in court and that even when litigation succeeds, court victories offer 'hollow hopes' (Rosenberg, 2008; Carter, 1992) bringing no real change. Other scholars express the concern that litigation is not only ineffective and a waste of resources, it is counterproductive in that courtscentered activism can hinder social struggle by preventing radical challenges to the status quo (Boutcher, 2013; Scheingold, 2004). Also Mubangizi and Twinomugisha (2010) and Ruger (2006) argue that litigation is unhelpful to the cause of vulnerable population except they are empowered for justice in their demand for an improved service delivery.

Despite the foregoing, literature has shown the extensive role of constitutional courts as agents of social change in democracies including Estonia (Maveety and Grosskopf, 2004), and Argentina (Walker, 2008). On the point, Mietzner (2010) demonstrates the effectiveness of the assertiveness of the Indonesian Constitutional Court in enforcing constitutional rights, while Ginsburg (2013) portrays the role of constitutional courts as triggers of democratic values and constitutional rights in South Korea, Taiwan, Thailand and Pakistan. Accountability through human rights actions, as noted by Gloppen and Roseman (2011), can change considerably the manner in which social delivery systems function. With particular reference to health care service delivery, as argued by Yamin (2011), the demand for justice by citizens for improved health facilities, can bring about positive impact on the health systems. Other authors indicate that it can trigger change in law or policy in such manner that ensures that a range of people are positively impacted (Peel and Osofsky, 2015; Liebenberg, 2012).

Official documents on the role of courts in South Africa, in particular the report by the Department of Justice and Constitutional Development (DOJ \& CD, 2012) show that considering the extensive power of courts to review legislative and executive action and by being able to hold them accountable, courts have a considerable influence over policy processes. Writing on the social transformative role of Constitutional Court of South Africa, Roux (2013) argues that since the 
transition to democracy in 1994, it has demonstrated how judicial enforcement of socio-economic rights, particularly the right to health, may be reconciled with a foundational commitment to democracy. This is confirmed in a more recent academic enquiry focusing on the right to health by Pieterse (2014), which demonstrates the positive impact of litigation on the health system. This possibility is expected given the 1996 Constitution which guarantees the right to health in its section 27, and the commitment of government to the right to health as discernible from its ratification of international human rights documents of importance to international standards on the right to health, such as the ICESCR in $2015,{ }^{2}$ the CRC in $1995^{3}$ and the CEDAW in $1995 .{ }^{4}$ It is also evident in its ratification of the African Charter on Human and Peoples' Rights in 1996.5

As mentioned earlier, the relevance of courts for accountability purpose in implementing MDGs is not mentioned in the 2015 MDGs report, but, access to justice featured in the 2013 MDGs report of South Africa (STATSSA, 2013) and remains a core component of the constitution as can be gleaned from its section 34 and international human rights instruments to which South Africa is a state party, such as Article 37(d) of CRC, Article 15 of CEDAW and Article 7 of the African Charter. A broader concept, the term 'access to justice' entails accountability beyond and within the courtrooms (Rodríguez-Garavito, 2011). Hence, the reference to access to justice in MDGs report signifies that it is legitimate to expect that access to justice cannot be isolated from future accountability beyond and within the courtroom, even if the commitments related to health under the SDGs do not have a binding status.

Beyond the courtroom, for instance, individuals and groups can engage organs of the State on issues which may shape the realisation of health-related SDGs. In implementing the SDGs, populations can expect activities and reports of government to evaluate health related SDGs from the prism of human rights. For instance, the government can be engaged on how goals relating to food security, good health and wellbeing and clean water and sanitation have informed the realization of the right to health as entrenched in the constitution and provisions of the international instruments. Such engagement can influence the design and implementation of programmes meant to achieve targets associated with these goals. Specifically, in relation to Goal 3 dealing with the human health, using the

2 'Status Ratification'. Available at: http://indicators.ohchr.org. Accessed 27th February, 2017.

3 Id.

4 Id.

5 African Commission on Human and Peoples' Rights 'Ratification Table: African Charter on Human and Peoples' Rights' . Available at: http://www.achpr.org/instruments/achpr/ratification/. Accessed 27th February, 2017. 
right to health as a benchmark can transform targets such as the reduction of maternal and child mortality, the tackling of AIDS and other diseases, as well as the provision of universal health coverage, affordable essential medicines, and sexual and reproductive health care from a mere statement of commitments into practical steps that can be taken by government to ensure the constitutional provision on the right to health in South Africa. Hence, even if SDGs do not have a legally binding status, they can test the sincerity of the commitment of the government to the realization of the right to health provision of the Constitution. It will be selfconflicting for a nation that retains the right to health provision in the constitution to take lightly its commitment under the SDGs related to health.

In relation to accountability within the court system, access to justice signifies that the textual provision of the constitution in relation to the right to health can be animated by making reference to targets underlying the health related SDGs, and doing so can have a bearing on the fulfilment of not just the SDGs but the realisation of the right to health as envisaged by the Constitution. While the right to health is subject to progressive realisation based on availability of resources (UN General Comment 14, 2000; Liebenberg, 2010), accountability before the court remains an important approach to test whether or not government is making sincere efforts to ensure progressive realisation of socio-economic rights and indirectly health related SDGs. That this is arguable is not difficult to imagine. There have been cases decided by the Constitutional Court where relying on section 27 and other relevant sections of the Constitution, the Court has ordered that positive measures be taken by the legislative and executive arms of government to further the realisation of the right to health. Even though such cases were not decided in the specific context of MDGs, such policy measures impacted positively on the policy environment for the implementation of the health-related MDGs, hence, they can influence the environment for the implementation of health related SDGs. In entertaining claims associated with the right to health, courts have served the important purpose of shaping health related MDGs and can impact on the implementation of health related SDGs as demonstrated by the outcome of certain decisions of Constitutional Court pertaining to the right to health on MDGs.

\section{As a Catalyst of Change in the Policy Environment}

In the Minister of Health and Others $v$ Treatment Action Campaign and Others, ${ }^{6}$ (TAC case) the Treatment Action Campaign (TAC) instituted an action against the government for refusing to extend the availability of the drug Nevirapine for use in the prevention of mother to child transmission (РМTCT) beyond the designated

6 Minister of Health and Others $v$ Treatment Action Campaign and Others (2002) 10 BCLR 1033 (CC) 
sites. Relying on the scientific evidence on the appropriateness of the drug and the reality that want of political will was the challenge to the availability of the drug to broader society, TAC contended that the policy restricting the availability of the drug was unreasonable, and accordingly that the State was in breach of its obligation to take 'reasonable legislative and other measures' to progressively realise the right to have access to health care services under section 27(1)(a) read with section 27(2) of the Constitution. The appeal of government to the Constitutional Court upon the successful outcome of the action at the Pretoria High Court was unanimously dismissed. The court accepted the argument by TAC that the policy restraining the distribution of drugs is unreasonable (para 113). Most significantly, in its judgement, the Court required the state to develop an 'effective and comprehensive' national plan on PMTCT.

There is evidence that the TAC decision has positively impacted the MDGs. Although actions which followed the decision can be linked to other activities such as social mobilisation and education by TAC (Heywood, 2009), the decision has positive implication for Goal 3 dealing with combating HIV/AIDS, as well as Goals 4 and 5 which focus on reducing child mortality and improvement of maternal health. For instance, a considerable part of the decision mandated the State to remove without delay the hurdle to wider availability of Nevirapine for the purpose of reducing the risk of mother-to-child transmission of HIV (para 135). In what reflects its positive impact, it was indicated that there has been a shift in the policy of government in relation to the extension of availability of the drug. The judgment led to a definite increase in access to Nevirapine by pregnant, HIV-positive women (Pieterse, 2014). It removed the restriction of access to ARV treatment for AIDS in the public health sector (Pieterse, 2014), and informed a new thinking in relation to the obligation of the State to the treatment of HIV and AIDS.

By focusing on mother-to-child transmission in a right to health action, the TAC decision serves the end of the three health related MDGs relating to combating HIV/AIDS, reducing child mortality and improvement of maternal health. This is an important precedent showing that the court can contribute positively in benchmarking the commitment of the State to health related SDGs, especially Goal 3 on health and well-being and Goal 10 on reduced inequality. This optimism agrees with the works of Maveety and Grosskpf (2004) who like many others, (Walker 2008), Mietzner (2010) and Ginsburg (2013) indicate that constitutional courts can enhance the realization of constitutional rights and consolidate democratic values. Equally, that the decision will contribute positively in benchmarking the commitment of the State to health related SDGs, especially Goal 3 on health and well-being and Goal 10 on reduced inequality can be legitimately expected due to 
the commitment of South Africa's government to obligations on the right to health in its constitution and under international human rights instruments to which it is a state party.

In New Clicks South Africa v Tshabalala-Msimang; Pharmaceutical Society of South Africa $v$ Tshabalala-Msimang (New Click case) ${ }^{7}$ 'New Clicks' group of retail pharmacies have vehemently opposed the intervention by the State to regulate the price regime of drugs with the purpose of making medicines more available. The actions were dismissed by the Cape High Court, but upheld by the Supreme Court of Appeal. In their final appeal to the Constitutional Court, TAC entered the matter as a friend of the court and supported the capping of profit margins of pharmaceuticals, but adduced evidence to show that prescribed dispensing fee by government regulation would have a downside as it could drive rural and courier pharmacies accessible to vulnerable group of patients out of business. In so far as the regulation constituted a threat to access to health care services by rendering medicines unavailable to patients served by rural and courier pharmacies, the Constitutional Court held that the dispensing fee was unreasonable and unconstitutional (para 19). Hence, it ordered that the specific regulations containing the dispensing be remitted to the relevant pricing committee for reconsideration in the light of the judgment (para 22(f)). The New Click case is useful because the order of Court called for the amendment of the regulation dealing with dispensing drugs, a development which indicates a positive role of court in influencing change in a legislation which would have constituted a further clog in the efforts towards achieving the health-related MDGs in South Africa. This decision offers an optimism that regulatory hindrances to the implementation of health related SDGs can be challenged and upturned, using the platform of the right to health.

The Law Society of South Africa $v$ Minister for Transport, (Law Society of South Africa case $)^{8}$ relates to access to health services within the private and public health sectors. The successful aspect of the case relates to amendments affected to the Road Accidents Fund Act 56 of 1996 and regulations proclaimed in terms thereof which limited the claims available to victims of road accidents to an amount determinable by the Uniform Patient Fee Schedule for fees payable to public health establishments by full-paying patients as prescribed under the National Health Act. ${ }^{9}$ In view of this provision, the court reasoned that quadriplegics and paraplegics would be 'constantly at risk in a state hospital as a result of the chronic

7 New Clicks South Africa v Tshabalala-Msimang; Pharmaceutical Society of South Africa $v$ TshabalalaMsimang (2005) 2 SA 530 (C)

8 Law Society of South Africa v Minister for Transport (2011) 2 BCLR 150 (CC).

9 Regulation 5(1) of 21 July 2008, issued under sec 17(4B)(a) of the National Health Act Act 61 of 2003 
lack of resources, paucity of staff and inexperience in dealing with spinal cord injuries' (paras 91-98) and consequently faced a 'material risk of untimely death due to untreated complications' (para 94). The Constitutional Court, then, held that the prescribed tariff unjustifiably infringed the right of access to health care services and recommended an amendment. In relation to the Law Society of South Africa case, as Pieterse (2014) notes, considering the costs associated with complying with the order, it may be rather early to assess the effects of the judgment on the South African health policy terrain. However, the future positive impact of this decision can be expected given the public health significance of road accidents as a driver of dreadful disability and mortality (WHO 2015: $\mathrm{x}$ ), the impact of the decision on the policy direction of health-related SDGs, in particular, Goal 3 which relates to good health and well-being.

Despite the above, courts' decisions are not always positive on the realisation of rights. For instance, there is an evidence of unwillingness or reluctance by the Court to order positive measures to ensure accessibility of water, despite its relevance to the actualisation of the right of every person to health. This is discernible from the decision of the Constitutional Court in Lindiwe Mazibuko and Others $v$ City of Johannesburg and Others ${ }^{10}$ (Mazibuko case). Though the case essentially deals with right to water, the Constitutional Court identified that water is important to healthy well-being. According to the Court, 'cultures in all parts of the world acknowledge the importance of water....without it, nothing organic grows. Human beings need water to drink, to cook, to wash and to grow our food' (para 1). The fact of the case is that Mrs Mazibuko and four other residents of Phiri, Soweto challenged, the City of Johannesburg's Free Basic Water policy in terms of which 6 kilolitres of water are provided monthly for free to all households in Johannesburg and, secondly, the lawfulness of the installation of pre paid water meters in Phiri. In addition to its ruling that the installation of pre-paid water meters in Phiri was unlawful and unfair and that the City's Free Basic Water Policy was unreasonable and unlawful, the South Gauteng High Court, ruled that the City should provide 50 litres of free basic water daily to the applicants and similarly placed' residents of Phiri. The order of 50 litres of free basic water daily was varied to 42 litres of water per day by the Supreme Court of Appeal which also directed the City to reformulate its policy and bye laws. However, in what seems a reversal of the decisions of the lower courts, the Constitutional Court held in contrast to the High Court and the Supreme Court of Appeal, that it is not appropriate for a court to give a quantified content to what constitutes 'sufficient water' because this is a matter best addressed in the first place by the government (para 61). Hence, the Court

10 Lindiwe Mazibuko and Others v City of Johannesburg and Others (2009) 8 BCLR 791 (SCA). 
reasoned that the contention of the applicant proposing the amount of 50 litres per person per day as necessary for dignified human life must fail (para 56).

The decision in Mazubiko case shows that on the subject of water which is connected to the right to health, the court may be reluctant to order positive measures, a development that can have a negative effect on the implementation of healthrelated SDGs. The effect can be negative in the sense that poor populations will have to pay for water beyond the free basic quantity made available by government. This direction by the Court in the Mazibuko case can undermine the relevance of Courts as an enabler of positive policy environment for the implementation of SDGs. It is inconsistent with Goal 6 which directly deals with clean water and sanitation and indeed other goals such as Goal 3 which expressly deals with ensuring healthy lives and promotion of well-being for all at all ages, in that living a healthy life is linked to adequate water. A population in a dire need of water will embark upon activities which may entail clearance of forests for water sources, a development which may undermine the realization of Goal 12 on sustainable consumption and production patterns, Goal 3 dealing with climate change and its impacts, and Goal 15 dealing with degradation and biodiversity loss.

The approach of the Court runs contrary to the well-founded reasoning of authors such as Liebenberg (2012), and Mbazira (2009) asserting that socio-economic rights litigation empowers the voice of the marginalized in their struggles over basic amenities. It confirms the fear that voices of the vulnerable poor may still be lost to legal technicalities of core minimum obligation of the State as stressed in the Mazibuko case (Couzens, 2015; Kidd, 2011; Dugard and Maohlakoana, 2009). The rejection of applicants' claims runs contrary to the well-founded position of authors including Yamin (2011) in that it denies them the opportunity to enforce their claim, entitlement to goods and services which are vital aspect of citizenship and their individual sense of identity as well as confidence in the policy regulating service delivery. Contrary to the position of authors such as Durojaye (2013), Liebenberg (2012), and Williams (1987) on the potency of human rights, the new direction indicates that individuals and marginalised groups within society are unable to assert themselves against powerful entities in the public and private spheres and, thereby, draw societal attention to their plight. This runs afoul of the consideration that water is an underlying determinant of health as clarified under General Comment No 14. It fails to take into consideration the salient notions in the general comment that require that determinant of healthy living should be available, accessible, culturally acceptable, and of appropriate scientific and medical quality. It is incompatible with the commitment of South Africa's government to obligations on the right to health under international human rights instruments 
which it has ratified including the ICESCR, CRC, CEDAW and the African Charter. It runs against the viewpoint of authors including Mubangizi and Twinomugisha (2010) and Ruger (2006) that human rights actions can aid service delivery and serve as a catalyst of policy change (Lomazzi et al., 2014; Lomazzi et al., 2012).

The foregoing decisions show that litigation can impact the policy environment of SDGs in South Africa, a conclusion which agrees with the viewpoint of authors including Mubangizi and Twinomugisha (2010), and Ruger (2006) that human rights actions can aid service delivery and serve as a catalyst of policy change (Lomazzi et al., 2014; Lomazzi et al., 2012).

\section{Courts as Agent of Social Mobilization for Health related SDGs}

Outcomes of litigation can both serve as an incentive or hindrance to mobilization approach for the implementation of health-related SDGs. While generally writing on the role of courts as an agent of social mobilization, Gloppen (2013) argues that courts provide a podium for articulating social rights concerns which may generate or strengthen popular debate and create political momentum. Durojaye (2013) indicates that human rights actions can enhance public awareness over an issue and avail individuals or groups with opportunities to redress human rights violations. This is indeed not unexpected, as Stammers (2009) argues, human rights evolve as part of social movement struggles. This viewpoint resonates in the context of South Africa where section 38 of the Constitution allows anyone to sue on behalf of others in courts. This connotes that social movements may engage in court-centered activism and that inspiration drawn from court cases where social movements have succeeded, can serve as a catalyst for transformation. For instance, the Treatment Action Campaign's court cases on access to HIV/AIDS medication in South Africa, demonstrates that court litigation can influence and be influenced by mobilization campaigns for change (Heywood, 2009). Hence, even if court presents an easy alternative to collective action, it may not work against the formation of strong social movements (Yamin, 2011).

Losing in court could damage the cause, delegitimize it, exhaust resources, and set back the struggle both politically and internally (Gloppen, 2013), but, social campaigns can still gain or win something from the loss (Yamin, 2011). It can influence other strategies beyond courtrooms for the realization of its objectives. This is particularly of importance in the context of SDGs. As Sachs_(2015) argues, goals are important for social mobilizing, as they can generate peer pressure, and spur communities into social actions. These communities, in the further view of the author, include politicians, government ministries, the scientific community, leading nongovernmental organizations, religious groups, international 
organizations, donor organizations, and foundations which can come together to achieve a purpose on which court direction is not clear or negative. This is not surprising as Zeleza (2004) notes, it is neither a court nor a book that ended apartheid, colonialism and slavery; meaning that mobilisation to achieve social change is not limited to courtrooms. As Baxi (2006: 184) put it, not the courtrooms alone, but the 'suffering and repressed people remain the primary authors of human rights values and visions.'

So construed, it means that court centered activism on heath related goals of the SDGs can be stimulated and inspired by changes brought about by the successful decisions in TAC and The New Click case. Activists can ensure the reflection of health related SDGs in the preparation and presentation of their claims before the court for adjudication. Also court actions can animate the implementation of the right to health provision with the commitment of government under the SDGs. Unlike the judgements considered thus far, this means that the analysis of SDGs can feature in courts decisions and activists can link SDGs more directly to the decisions of the Constitutional Court and its transformative agenda. Besides, the possibility of linking health related SDGs to court decisions will further assist social activists working on SDGs to use such judgements to create pressure, and mobilize their networks in ensuring that government performs its commitment under the SDGs as they affect the right to health.

Where there is a judgement of the Constitutional Court, such as in Mazibuko case which is not pro-poor, the consequence on social struggle for human rights can be both negative and positive. One might say that this could damage the realization of the targets under the health related SDGs and delegitimize the efforts of activists in line with the general arguments by Gloppen (2013) on the effect of losing a cause in court. For instance, being a case delivered by the highest court in the land, the Mazibuko case can be used by government at the national, provincial and municipal levels, not only as response to legitimate campaigns in relation to the attainment of Goal 6 which directly deals with the provision of clean water and sanitation and of course the realization of access to water, it may be used as a legal basis to repel the efforts of activists to mobilise community leaders, local populations, and religious groups, to ensure the attainment of this goal. Furthermore, it can constitute a disincentive to court centered activism in that the outcome may have sent the signal that it is of little or no worth to the poor to approach the Constitutional Court for the realization of the right to access to water and serves as a wrong precedent for court based activism that can help in the realization of other SDGs.

While a favourable decision of courts is desirable for activism purpose, an unpopular decision by court can trigger the mobilization for campaigns elsewhere 
outside the court. Such campaigns outside the court may in fact lead to a change of law, a development which can affect future interpretations of law and decisions by court. For instance, such a court decision does not prevent the lobbying of politicians, mobilization of local populations and other networks for change in law or government approach towards its commitments to health related SDGs. A decision such as given in Mazibuko case can strengthen activists' arguments in relation to access to water in South Africa. For instance, it can help sustain the argument that the direction of court may undermine government commitments under the SDGs and its obligation to achieve the rights to access water provision of the Constitution. Hence, even where decisions by courts are not favourable, they can still be positively engaged by social activists to achieve the commitments by government to health related targets of the SDGs in South Africa.

\section{Conclusion}

Health related SDGs, just as their MDG counterparts, are connected and compatible with international standard on the right to health as guaranteed in international human rights instruments. As has been shown, through a number of its decisions on the right to health, the Constitutional Court has positively impacted the policy environment of health-related MDGs in a way that will be of importance to the policy environment of the health related SDGs. It has served and can still serve as a platform of accountability, a catalyst of change in the policy environment, and as a catalyst of social mobilization for the implementation of SDGs. As a platform of accountability, it can be engaged to hold the state accountable for SDG health related goals. Actions aimed at accountability have shaped MDGs environment, hence, can serve as a catalyst for positive change of the SDG health related goals while the result of actions in courts can aid or hinder social mobilization for health related SDGs. In implementing the SDG health related goals, government and indeed other stakeholders should take into consideration the importance of courts as a platform of accountability, a catalyst of change in the policy environment and agent of social mobilization for health related SDGs in South Africa. 


\section{References}

African (Banjul) Charter on Human and Peoples' Rights, adopted 27 June 1981, OAU Doc. CAB/LEG/67/3 rev. 5, 21 I.L.M. 58 (1982), entered into force 21 October 1986 .

Alston, P. (2005). Ships passing in the night: The current state of the human rights and development debate seen through the lens of the millennium development goals. Human Rights Quarterly, 27(3), pp. 755-829.

Baxi, U. (2006). Politics of reading human rights: Inclusion and exclusion of human rights. In S. Meckled-Garcia and B. Cali (Eds.), The legalisation of human rights: Multidisciplinary perspectives on human rights and human rights law, pp. 182200. New York: Routledge.

Boutcher, S.A. Law and social movements: It's more than just litigation and courts (online). Available at: https://mobilizingideas.wordpress. com/2013/o2/18/law-and-social-movements-its-more-than-just-litigationand-courts//.Accessed 1oth January, 2017.

Carter, S. L. (1992). Do Courts Matter? Faculty Scholarship Series. Paper 2255 (online). Available at: http://digitalcommons.law.yale.edu/fss_papers/2255. Accessed 10th January, 2017.

Convention on the Elimination of All Forms of Discrimination against Women, Treaty Series 1249.1988. (online). Available at: http://www.ohchr. org/Documents/ProfessionalInterest/cedaw.pdf. Accessed th February, 2017.

Convention on the Rights of Persons with Disabilities : Resolution, adopted by the General Assembly, 24 January 2007, A/RES/61/106.

Convention on the Rights of the Child (CRC), G.A. Res. 44/25. 1989. (online). Available at: http://www2.ohchr.org/english/law/crc.htm. Accessed 1oth February, 2017.

Couzens, E. (2015). Avoiding Mazibuko: Water security and constitutional rights in Southern African case law. PER / PELJ, 18 (4), pp.1161-1185.

DOJ and CD (Department of Justice and Constitutional Development). (2012). Republic of South Africa Discussion Document on the Transformation of the Judicial System and the Role of the Judiciary in the Developmental South African State (online). Available at: http://blogs.sun.ac.za/seraj/files/2013/10/ SERAJ-Submission-on-the-Judicial-Discussion-Document1.pdf. Accessed 1oth February, 2017. 
Dugard, J. and Maohlakoana, N. (2009). More work for women: A rights-based analysis of women's access to basic services in South Africa. South African Journal on Human Rights, 25(3), pp. 546-572.

Durojaye, E. (2013). So sweet, so sour: A commentary on the Nigerian High Court's decision in Georgina Ahamefule v Imperial Hospital \& Another Relating to the Rights of Persons Living with HIV. African Human Rights Law Journal, 13(2), pp. 464-48o.

Fehlinga, M., Nelson, B.D. and Venkatapuram, S. (2013). Limitations of the millennium development goals: A literature review. Global Public Health, 8 (10), pp.1109-1122.

Forman, L., Ooms, G., Chapman, A., Friedman, E., Waris, A., Lamprea, E. and Mulumba, M. (2013). What could a strengthened right to health bring to the post-2015 health development agenda?: Interrogating the role of the minimum core concept in advancing essential global health needs. BMC International Health and Human Rights, pp. 13:48 (online). Available at: http://bmcinthealthhumrights.biomedcentral.com/articles/10.1186/1472698X-13-48. Accessed 11th February, 2017.

Fukuda-Parr, S., Birdsall, N. and Sachs, J. (2003). Millennium Development Goals: A Compact Among Nations to end Human Poverty. Oxford: Oxford University Press.

Ghai, Y. and Cottrell, J. (2011). The Millennium Declaration, Rights, and Constitutions. Oxford: Oxford University Press.

Ginsburg, T. (2013). The politics of courts in democratization: Four junctures in Asia. In D. Kapiszewski, G. Silverstein. and R.A. Kagan (Eds.), Consequential Courts: Judicial Roles in Global Perspective, pp. 45-46. Cambridge: Cambridge University Press.

Gloppen, S. (2013). Social movement activism and the courts (online). Available at: https://mobilizingideas.wordpress.com/2013/o2/o4/social-movementactivism-and-the-courts/. Accessed 11th February, 2017.

Gloppen, S. and Roseman, M.J. (2011). Introduction: Can Litigation bring Justice to Health? In A.E. Yamin and S. Gloppen (Eds.), Litigating health rights: Can courts bring more justice in health, pp. 1-16. Harvard: Harvard University Press.

Gloppen, S. (2008). Litigation as a strategy to hold governments accountable for implementing the right to health. Health and Human Rights Journal, 10 (2), pp. 21-36. 
Heywood, M. (2009). South Africa's Treatment Action Campaign: Combining law and social mobilization to realize the right to health. Journal of Human Rights Practice, 1(1), pp. 14-36.

Hulme, D. (2009). The millennium development goals (MDGs): A short history of the world's biggest promise. Brooks World Poverty Institute Working Paper 100. University of Manchester.

Kidd, M. (2011). Environmental Law (2nd ed.). Cape Town: Juta.

Liebenberg, S. (2012). Engaging the paradoxes of the universal and particular in human rights adjudication: The possibilities and pitfalls of 'meaningful engagement. African Human Rights Law Journal, 12(1), pp. 1-29.

Liebenberg, S. (2010). Socio-economic rights: Adjudication under a transformative constitution. Cape Town: JUTA.

Lomazzi, M., Borisch, B. and Laaser, U. (2014). The millennium development goals: Experiences, achievements and what's next. Global Health Action, 7(10), pp. 1-9.

Lomazzi, M., Theisling, M., Tapia, L., Borisch, B. and Laaser. U. (2012). MDGs-A public health professional's perspective from 71 countries. Journal of Public Health Policy, 34(1), pp.1-22.

Maveety, N. and Grosskopf. A. (2004). "Constrained" constitutional courts as conduits for democratic consolidation. Law \& Society Review, 38 (3), pp. 46388.

Mbazira, C. (2009). Litigating socio-economic rights in South Africa: A choice between corrective and distributive justice. Pretoria: Pretoria University Law Press.

Mietzner, M. (2010). Political conflict resolution and democratic consolidation in Indonesia: The role of the Constitutional Court. Journal of East Asian Studies, 10(3), pp. 397-424.

Mubangizi, J.C., and Twinomugisha, B.K. (2010). The right to health care in the specific context of access to HIV/AIDS medicines: What can South Africa and Uganda learn from each other? African Human Rights Law Journal, 10 (1), pp. 105-134.

Nelson, P.J. (2007). Human rights, the millennium development goals, and the future of development cooperation. World Development, 35 (12), pp. 2041-2055.

OHCHR. (2008). Claiming the Millennium Development Goals: A Human Rights Approach. 
OHCHR. (2010). Human Rights and the Millennium Development Goals in Practice: A Review of Country Strategies and Reporting . (online). Available at: http:// www.ohchr.org/Documents/Publications/HRAndMDGsInPractice.pdf.

Accessed 8th February, 2017.

Open Working Group on Sustainable Development Goals. (online). Available at: http:// sustainabledevelopment.un.org/owg.html. Accessed 8th February, 2017.

Peel, J., and Osofsky, H.M. (2015). Climate change litigation: Regulatory pathway to cleaner energy. Cambridge: Cambridge University Press.

Persson, A., Weitz, N. and Nilsson, M. (2016). Follow-up and review of the sustainable development goals: Alignment vs. internalization. RECIEL, 25 (1), pp. 59-68.

Pieterse, M. (2014). Can rights cure?: The impact of human rights litigation on South Africa's health system. Pretoria: Pretoria University Law Press.

Rodríguez-Garavito, C. (2011). Beyond the courtroom: The impact of judicial activism on socioeconomic rights in Latin America. Texas Law Review, 89, pp. 1669-1698.

Rosenberg, G.N. (2008). The hollow hope: Can courts bring about social change? (2nd ed.). Chicago: University of Chicago Press.

Roux, T. (2016). Constitutional courts as democratic consolidators: Insights from South Africa after 20 years. Journal of Southern African Studies, 42 (1), pp. 5-18

Roux, T. (2013). The politics of principle: The first South African Constitutional Court, 1995-2005. Cambridge: Cambridge University Press.

Ruger, J.P. (2006). Towards a theory of a right to health: Capability and incompletely theorized Agreements. Yale Journal of Law \& the Humanities, 18 (2), pp. 273 326.

Sachs, J.D. (2015). Why the Sustainable Development Goals Matter'. (online). Available at: www.project-syndicate.org/commentary/sustainabledevelopment-goals-shift-by-jeffrey-d-sachs-2015-03. Accessed 10th February, 2017.

Scheingold, S. A. (2004). The politics of rights: Lawyers, public policy, and political change ( 2 nd ed.) Ann Arbor: University of Michigan Press.

Stammers, N. (2009). Human rights and social movements. London: Pluto Press 
STATSSA (Statistics South Africa). (2015). Millennium Development Goals: Country Report 2015. Statistics South Africa. (online). Available at: http://www.statssa. gov.za/MDG/MDG_Country\%2oReport_Final3oSep2015.pdf.

\section{Accessed 10th April, 2017.}

UN CDP. (2015). Transitioning from the MDGs to the SDGs: Accountability for the Post-2015 Era. (UN Doc. ST/ESA/2015/CDP/25, June 2015).

UNDP. (2016). From the MDGs to Sustainable Development for All: Lessons from 15 years of Practice. United Nations Development Programme.

UNDP. (2015). Human Development Report 2015: Work for Human Development. United Nations Development Programme.

UNGA Resolution 70/1. (2015). Transforming our world: the 2030 Agenda for Sustainable Development. UN Doc. A/RES/70/1 (25 September 2015). (online). Available at: www.un.org/en/ga/7o/resolutions.shtml. Accessed 1oth March, 2017.

UNGA Resolution. A/RES/55/2. (2000). United Nations Millennium Declaration. New York: United Nations. 18 December 200o. (online). Available at: http:// www.un.org/millennium/declaration/ares552e.htm. Accessed 8th March, 2017.

United Nations General Comment No.14. (2000). The Right of Everyone to the Enjoyment of the Highest Attainable Standard of Health, UN Doc. No E/C.12/200o/4.

United Nations. (2000). Official list of MDG indicators. (online). Available at: http:// www.mdgs.un.org/unsd/mdg/Host.aspx?Content_Indicators/OfficialList. htm. Accessed 8th March, 2017.

United Nations. (2004).The right of everyone to the enjoyment of the highest attainable standard of physical and mental health Report of the Special Rapporteur, Paul Hunt. E/CN.4/2004/49 (16 February 2004). (online). Available at: https://documents-dds-ny.un.org/doc/UNDOC/GEN/Go4/109/33/PDF/ G0410933.pdf?OpenElement. Accessed 11th March, 2017.

Universal Declaration of Human Rights, G.A. Res. 217A (Ill), U.N. Doe. A/810. (1948).

Unterhalter, E. (2013). Education Targets, Indicators and a Post-2015 Development Agenda: Education for All, the MDGs, and Human Development'. Institute of Education, University of London Working Paper Series. (online). Available at: https://cdn2.sph.harvard.edu/wp-content/uploads/sites/5/2013/og/ Education-MDGs-Draft-4_Working-Paper.pdf. Accessed 1oth April, 2017. 
Walker, C.J. (2008). Toward democratic consolidation: The Argentine Supreme Court, judicial independence, and the rule of law. High Court Quarterly Review, 4(3), pp. 54-101.

WHO. Millennium Development Goals (MDGs). (online). Available at: http:// www.who.int/mediacentre/factsheets/fs29o/en/. Accessed 1oth April, 2017.

WHO. (2015). Global Status Report on Road Safety. WHO

Williams, P.J. (1987). Alchemical notes: Reconstructing ideals from deconstructed rights. Harvard Civil Rights Civil Liberties Law Review, 22, pp. 401-433.

Yamin, A.E. (2011). Power, suffering, and courts: Reflections on promoting health rights through judicialisation. In A.E. Yamin and S. Gloppen (Eds.), Litigating health rights: Can courts bring more justice in health, pp. 333-372, Harvard: Harvard University Press.

Zeleza, P.T. (2004). Introduction: The struggle for human rights in Africa. In P.T. Zeleza and P. J. McConnaughay (Eds.), Human rights, the rule of law and development in Africa, pp. 1-19, Philadelphia: University of Pennsylvania Press. 